\title{
Analisis Sedimentologi dan Stratigrafi untuk Rekonstruksi Model Lingkungan Pengendapan: Mengungkap Proses Pembentukan Formasi Tapak, Sub-Cekungan Banyumas
}

\author{
Rian Cahya Rohmana ${ }^{1}$, Ali Achmad ${ }^{2}$, Suyoto $^{2}$ \\ ${ }^{1}$ Tanri Abeng University, Jl. Swadarma Raya Blok Haji Rohimin No.58, Ulujami, Kec. Pesanggrahan, \\ Kota Jakarta Selatan, DKI. Jakarta, \\ ${ }^{2}$ UPN "Veteran" Yogyakarta, Jl. SWK No.104, Ngropoh, Condongcatur, Kec. Depok, Kabupaten Sleman, \\ D.I. Yogyakarta
}

\begin{abstract}
Abstrak
Objek studi difokuskan pada Formasi Tapak yang terendapkan pada Miosen Akhir - Pliosen Akhir di Sub-Cekungan Banyumas. Pengungkapan serta rekonstruksi model lingkungan pengendapan purba didasarkan pada analisis detail sedimentologi dan stratigrafi yang meliputi tekstur, struktur sedimen, asosiasi fasies, paket sekuen pengendapan, kandungan fosil, geometri pelamparan secara vertikal maupun horisontal serta pengukuran arah arus purba pada daerah penelitian. Fasies yang berkembang pada Formasi ini cukup bervariasi yaitu lagoonal pond, tidal channel in foreshore facies, upper shoreface - shelf mud facies. Secara regional Formasi Tapak diendapkan dalam suatu sistem pada lingkungan pengendapan lagoon hingga laut dangkal. Pada daerah penelitian juga ditemukan batugamping terumbu yang terbentuk pada barrier reef. Dari Hasil pengukuran arus purba pada struktur sedimen trough crossbedding pada lokasi pengamatan Banyumas - 14, terlihat bahwa arah umum dari transportasi sedimennya berasal dari Barat-Laut menuju ke Tenggara.
\end{abstract}

Kata kunci: Sedimentologi; Stratigrafi; Lingkungan Pengendapan; Formasi Tapak.

\section{Abstract}

The object of study is focused on The Tapak Formation deposited in Late Miocene - Late Pliocene in the Banyumas Sub-Basin. Reconstruction of the paleo-environment model is based on detailed analysis of sedimentology and stratigraphy which includes textures, sedimentary structures, facies associations, depositional sequence packages, fossil content, vertical and horizontal geometry and measurement of paleocurrents in the study area. Facies in this formation namely lagoonal pond, tidal channel in foreshore facies, upper shoreface shelf mud facies. Regionally, The Tapak Formation was deposited in the lagoon deposition to the shallow sea environment. In the study area also found reef limestone formed on the barrier reef. From the results of paleocurrents measurements in the trough crossbedding sedimentary structure, it appears that the general direction of sediment transport originated from The Northwest to The Southeast.

Keywords: Sedimentology; Stratigraphy; Paleogeography; Tapak Formation.

\section{PENDAHULUAN}

Lingkungan pengendapan purba dapat digunakan untuk memprediksi suatu distribusi batuan sedimen yang terendapkan dalam suatu lingkungan tertentu. Pemahaman mengenai modelnya dapat digunakan untuk menganalisis dinamika yang terjadi pada cekungan sedimenter. Formasi Tapak menurut Kastono dan Suwarna (1996) berumur Pliosen AwalAkhir. Lokasi tipe dari formasi ini diambil dari sebuah nama gunung di wilayah Kabupaten Brebes yaitu Gunung Tapak, sedang Lokasi tipenya terletak pada hulu sungai Cipanaas, sekitar $2 \mathrm{~km}$ sebelah barat-laut bentasari. Fokus

*) Korespondensi: rian@tau.ac.id 
penelitian ini untuk mengetahui lingkungan pengendapan dan membuat model lingkungan pengendapan Formasi Tapak. Hal tersebut dilakukan untuk dapat mengetahui pola distribusi batuan dan mekanisme pembentukannya. Formasi Tapak disusun oleh satuan batulempung - gampingan Tapak dengan Satuan batugamping Anggota Darmakradenan. Selain itu, penelitian ini diharapkan menjadi sumbangsih dalam hal keilmuan geologi sebagai informasi awal dalam melakukan eksplorasi sumber daya alam pada daerah Banyumas dan sekitarnya.

\section{Geologi Regional}

Secara fisiografi daerah penelitian termasuk ke dalam Zona Jalur Pegunungan Serayu Selatan (Van Bemmelen, 1949) dan secara administratif terletak pada Kecamatan Ajibarang dan Gumelar Kabupaten Banyumas (Gambar 1). Secara struktural, daerah penelitian merupakan daerah rendahan yaitu Wangon Depression (Sujanto dan Roskamil, 1975). Sub-Cekungan Banyumas ini pada bagian barat laut dan utara di batasi oleh Tinggian Majenang, Bagian barat di batasi oleh Tinggian Besuki, Bagian timur di batasi oleh Tinggian Karangbolong (Muchsin dkk., 2002), dan bagian Selatan melampar daerah rendahan Banyumas - Kroya. Urutan stratigrafi pada SubCekungan Banyumas mengacu pada Satyana (2007). Secara umum urutan formasi yang mengisi Cekungan ini adalah sedimen volkaniklastik yang terendapkan oleh pengaruh arus turbid (Gambar 2).

\section{METODOLOGI}

Penelitian ini melakukan analisis profil sedimentologi dan stratigrafi detil dari singkapan batuan Formasi Tapak pada daerah penelitian. Metode pengukuran penampang stratigrafi menggunakan pita ukur dan kompas. Metode ini diterapkan terhadap singkapan yang menerus atau sejumlah singkapan-singkapan yang dapat disusun menjadi suatu penampang stratigrafi. Pengukuran profil dan stratigrafi umumnya dilakukan pada singkapan yang menerus. Data yang diambil meliputi tekstur, struktur sedimen, komposisi mineral, sekuen pengendapan (mengkasar ke atas/menghalus keatas), kontak lapisan (erosional, gradasional, tegas).
Selain itu, data fosil megaskopis maupun mikoskopis juga digunakan dalam penelitian ini. Data geometri pelamparan lapisan batuan, serta pola suksesi penumpukan sedimen (penebalan/penipisan) juga menjadi data yang akan diintegrasikan dalam penelitian ini. Dari integrasi data tersebut, akan dibangun model sejarah lingkungan pengendapan dan pengendapan Formasi Tapak pada daerah penelitian.

\section{HASIL}

Gambaran model lingkungan pengendapan Formasi Tapak pada daerah penelitian, pengambilan data di fokuskan pada lima lokasi pengamatan Banyumas dengan kode BMS-76, BMS-77, BMS-111, BMS-14 dan BMS-35 (lokasi penelitian dapat diamati dalam Gambar 1). Pemilihan kelima lokasi di atas berdasarkan kualitas data yang baik dan memungkinkan untuk diukur dan diamati. Berikut adalah pembahasan masing-masing lokasi pengamatan.

\section{Lokasi pengamatan Banyumas-76}

Pada lokasi pengamatan ini terdapat perlapisan batulempung tebal dengan sisipan batupasir berukuran butir pasir halus $(1 / 8 \mathrm{~mm}-1 / 4 \mathrm{~mm})$. Batupasir tersebut memiliki hubungan kontak erosional pada bagian dasar lapisannya, selain itu batupasir ini kaya akan debris (reworked) dari cangkang organisme laut dari jenis palecypoda. Struktur sedimen yang ditemui yakni perlapisan sejajar, perlapisan bersusun dan hummocky cross-stratification. Ukuran butir pada singkapan ini memiliki pola penghalusan ke atas. Batulempung bersifat karbonatan yang mengindikasikan litologi ini terendapkan di lingkungan laut. Dari hasil tes kalsimetri menunjukan kandungan $\mathrm{CaCo}_{3}$ adalah $41,8 \%$ dengan nama napal. Dari hasil analisis petrografi memperlihatkan adanya fragmen mineral plagioklas. Hal tersebut mengindikasikan bahwa sumber sedimen pada satuan batulempung-gampingan Tapak sebagian besar material asal darat. Interpretasi mengenai fasies lingkungan pengendapan pada lokasi BMS-76 ini memiliki karakter fasies transition zone to shelf mud (Reineck and Singh, 1980) sedangkan dari model Nichols (2009) adalah offshore transition-offshore (Gambar 3). 


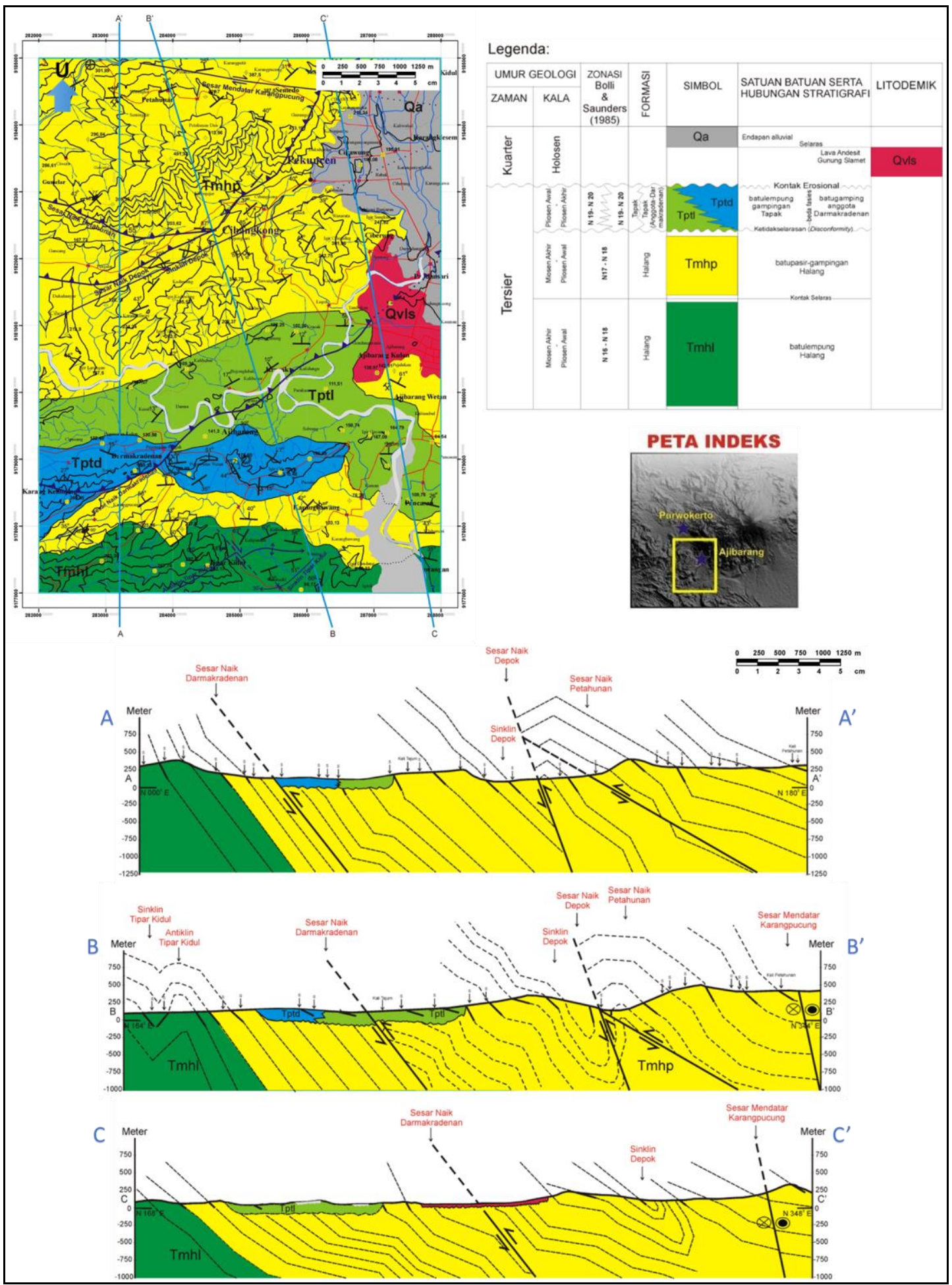

Gambar 1. Peta Geologi (modifikasi dari Djuri dkk., 1996; Kastowo dan Suwarna, 1996) dan penampang geologi pada daerah penelitian, masuk ke dalam zona Jalur Pegunungan Serayu Selatan. Formasi Tapak (Tptl) pada gambar diatas berwarna hijau muda.

\section{Lokasi pengamatan BMS-77}

Singkapan pada lokasi ini terdiri dari batulempung (tebal $15-20 \mathrm{~cm}$ ) dengan sisipan batupasir. Batu lempung ini bersifat karbonatan, warnanya gelap, yang menunjukkan adanya pengaruh dari sistem lingkungan pengendapan yang tertutup. Batulempung ini juga mengandung fragmen palecypoda dengan bentuk ulir yang masih cukup halus, serta hiasan yang tidak begitu kompleks. Palecypoda 


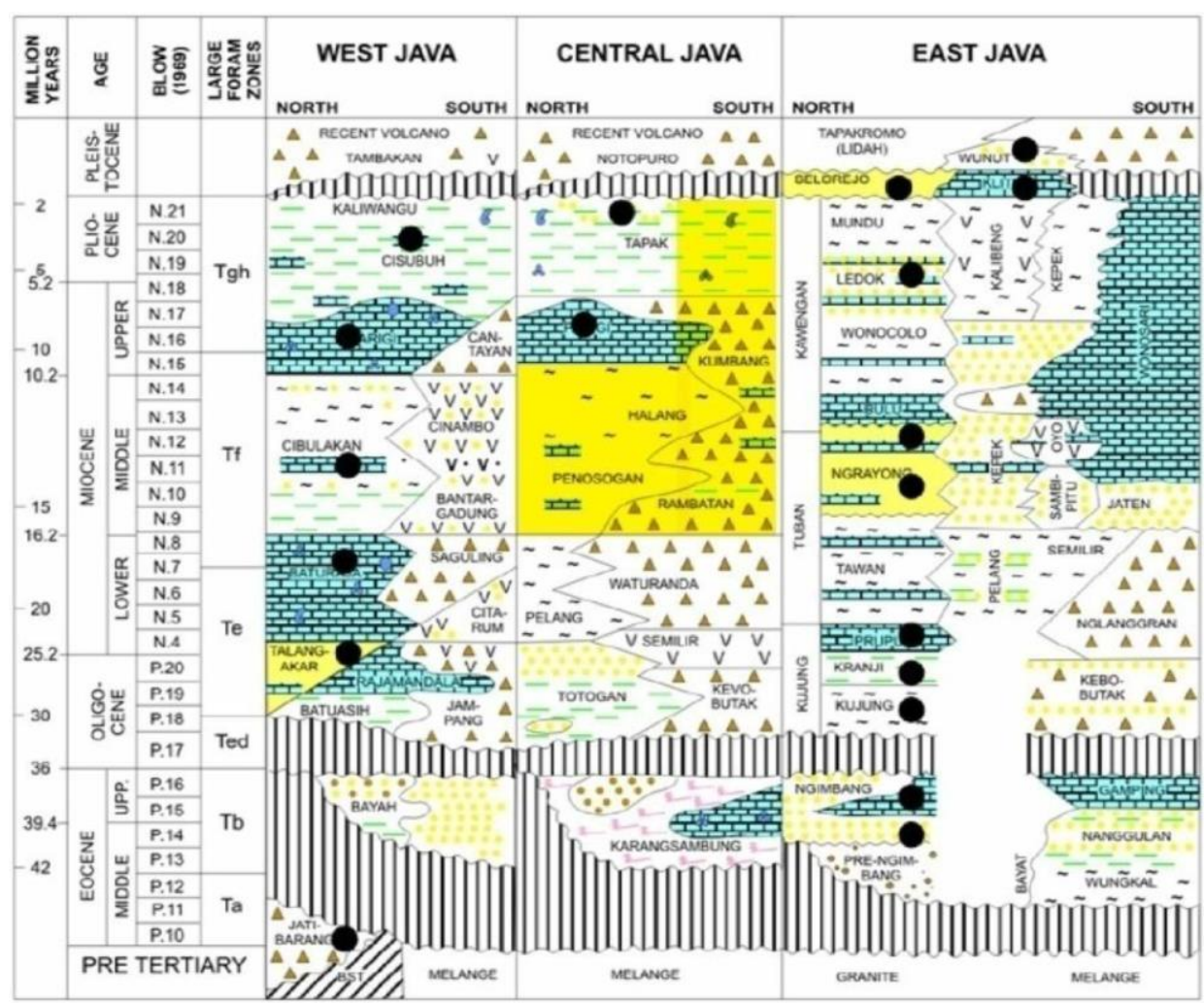

Gambar 2. Urutan stratigrafi pada Sub-Cekungan Banyumas mengacu pada Satyana (2007).

tersebut diperkirakan masih hidup pada lingkungan transisi. Struktur sedimen yang berkembang adalah masif dan perlapisan sejajar. diinterpretasikan bahwa lapisan ini terendapkan dalam fasies lingkungan lagoonal pond (Reineck \& Singh, 1980) dan fasies lingkungan lagoon (Nichols, 2009) (Gambar 4).

\section{Lokasi pengamatan BMS-111}

Pada bagian bawah singkapan di lokasi pengamatan ini tersusun atas sekuen napal tebal kaya akan foraminifera planktonik. Hasil analisis paleontologi mikro pada sasmpel napal didapatkan umur N.20 (Pliosen Awal-Pliosen Akhir) zonasi Bolli \& Saunders, (1985), termasuk dalam satuan batulempung-gampingan Tapak. Pada napal terdapat pecahan fragmen tuff yang diduga berasal dari tuff Formasi Halang yang telah mengalami sedimentasi ulang. Selain itu juga ditemukan bioturbasi berupa Thallasinoides sebagai penciri substrat pada lingkungan laut dangkal (semi consolidate materials). Bentuk geometri dari fosil jejak tersebut memiliki panjang sekitar $8 \mathrm{~cm}$ dan lebar $5 \mathrm{~cm}$, bentuk percabangannya segitiga. Pada bagian atas terdapat batupasir dengan struktur sedimen perlapisan bersusun, bagian dasarnya terdapat material butiran tuff berukuran $1 \mathrm{~mm}-2$ mm. Komposisi mineral didominasi atas material asal darat seperti, kuarsa, plagioklas, piroksen dan sedikit kalsit. Terdapat sisa hancuran cangkang organisme laut seperti moluska.Struktur sedimen yang dijumpai adalah laminasi sejajar yang merupakan hasil sedimentasi material sedimen dengan mekanisme traksi pada sistem rezim aliran bawah. Sekuen yang tersusun pada singkapan ini memperlihatkan adanya perubahan fasies pengendapan pada sistem lingkungan pengendapan pantai - laut. Fasies yang berkembang tersebut adalah upper shoreface shelf mud (Reineck and Singh, 1980) dan shoreface - offshore (Nichols, 2009).

\section{Lokasi pengamatan BMS-14}

Salah satu kunci dalam pengungkapan model lingkungan pengendapan daerah penelitian adalah singkapan batupasir Tapak pada lokasi ini. Penulis melakukan pengukuran arah arus purba yang menjadi data penting untuk merekonstruksi arah transportasi sedimennya. Pada bagian bawah singkapan ini secara umum disusun oleh klastika kasar dengan ukuran kerikil, pasir kasar hingga medium dengan ketebalan $21 \mathrm{~cm} \mathrm{~cm}$. Pada bagian bawah dari singkapan ini tersusun atas batupasir krikilan 


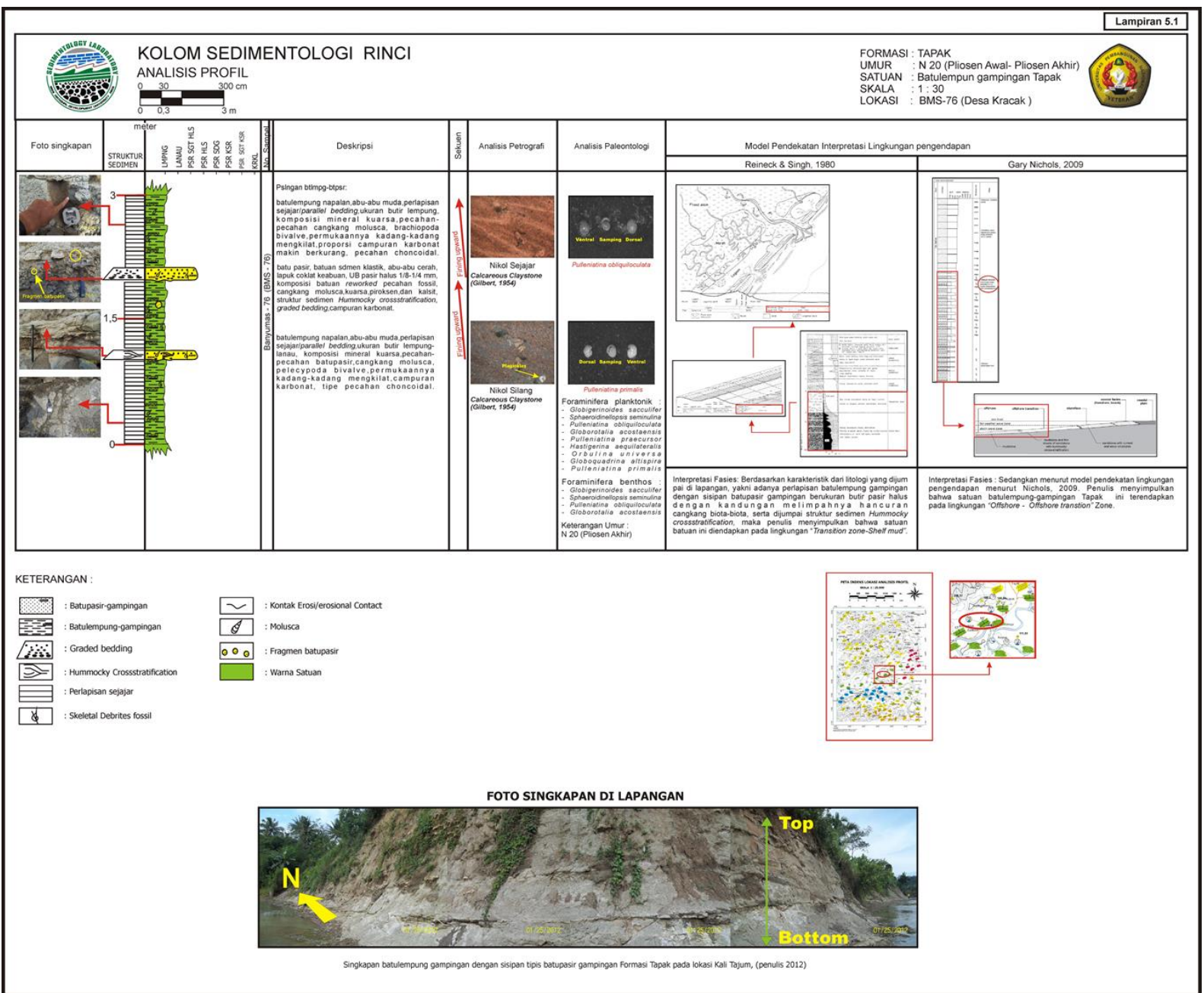

Gambar 3. Analisis profil dan interpretasi model lingkungan pengendapan pada lokasi pengamatan BMS-76 Formasi Tapak.

dengan fragmen batupasir, batulempung dan tuff, matriks lempung hingga lanau bersifat karbonatan.Batupasir ini memiliki karakter berwarna abu-abu cerah, warna lapuk coklat, sortasi jelek, porositas sedang, kemas terbuka, agak kompak, pada bawah sekuen ini terdapat struktur sedimen trough crossbedding dan laminasi sejajar pada bagian atas sekuen. Pola penumpukan lapisan batuan, menunjukan penghalusan dan penipisan ke atas. Data penting lain pada singkapan ini terdapat heringbone crossbedding sebagai indikator lingkungan yang memiliki dua rezim aliran yang berlawanan arah (bimodal currents). Struktur sedimen khas tersebut dijumpai pada lingkungan transisi khususnya fasies lingkungan tidal channel. Hasil pengukuran foresets struktur sedimen tersebut, arah arus purba relatif Barat Laut ke Tenggara. Melalui hasil penghitungan data secara statistik diperoleh arah umum pada diagram roset $\mathrm{N} 328^{\circ} \mathrm{E}-148^{\circ} \mathrm{E}$. Diinterpretasikan batupasir ini terendapkan pada lingkungan foreshore facies (Reineck dan Singh, 1980) dan lingkungan Scour Base Channel-Tidal Channel Zone (Nichols, 2009) (Gambar 5).

\section{Lokasi pengamatan BMS-35}

Litologi yang terdapat dalam singkapan ini terdiri atas kalkarenit dengan sisipan kalsilutit. Kalkarenit berwarna kuning keabuan, ukuran butir pasir sedang $(1 / 4 \mathrm{~mm}-1 / 2 \mathrm{~mm})$, terpilah baik, kemas tertutup, kompak, komponen utama tersusun atas kalsit, fosil foraminifera. Terdapat kuarsa, semen karbonat, struktur sedimen hanya perlapisan sejajar dan laminasi sejajar.

Hasil dari analisa sayatan tipis batuan diperoleh nama batuan foraminifera packestone (Dunham, 1962). Dapat disimpulkan bahwa 


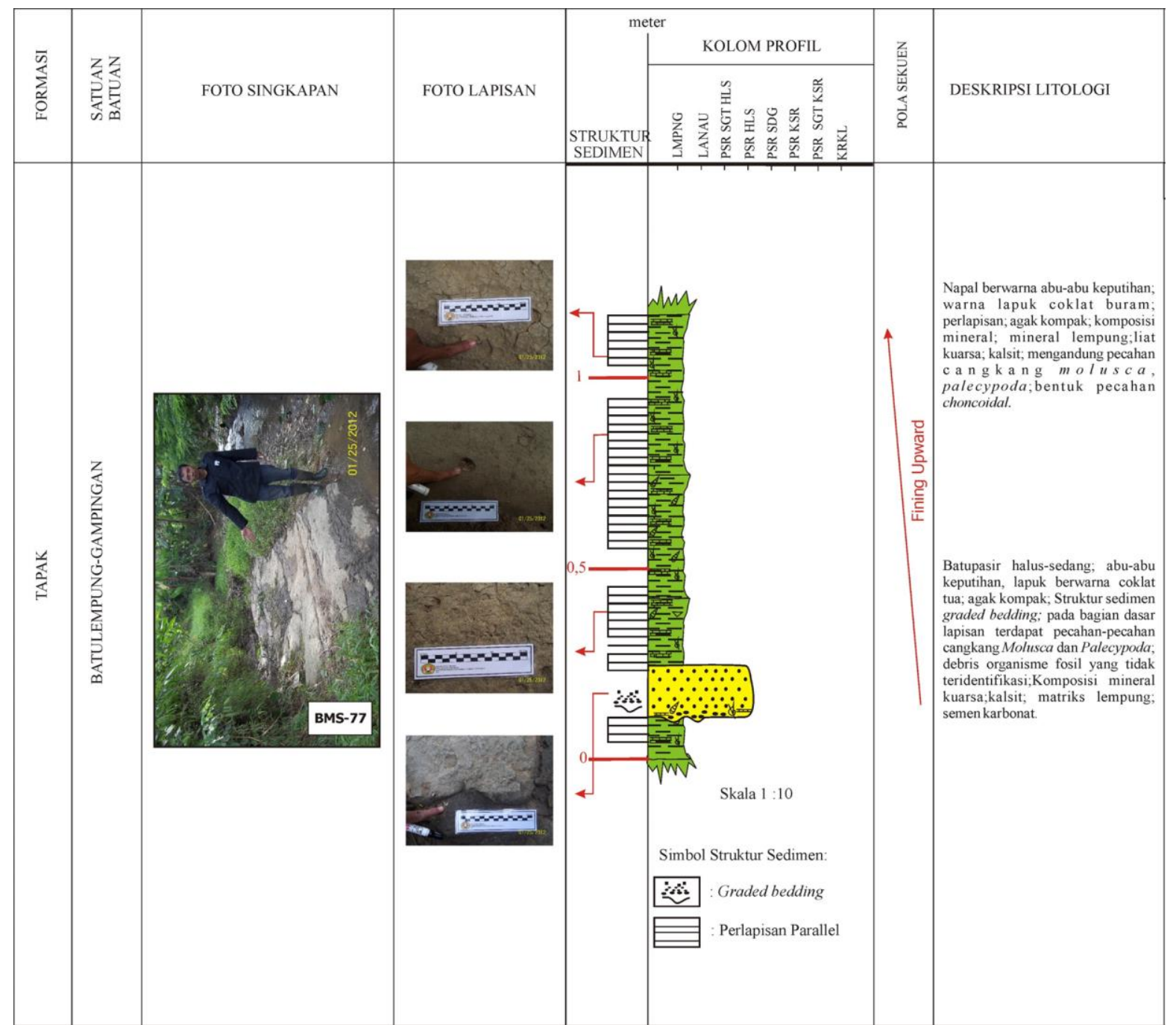

Gambar 4. Analisis profil dan interpretasi model Lingkungan pengendapan pada lokasi pengamatan BMS-77 Formasi Tapak.

kalkarenit ini terendapkan pada fasies winnow edge sands (Wilson 1975), sedangkan berdasarkan klasifikasi Walker \& James, 1992 dalam Nichols (2009) disimpulkan kalkarenit tersebut diendapkan pada sand appron di lingkungan Open shelf.

\section{PEMBAHASAN}

Integrasi semua data geologi meliputi fasies lingkungan pengendapan, umur, tipe reff karbonat, arah arus purba dan sebaran yang digambarkan peta geologi menjadi dasar penyusunan sejarah geologi serta kondisi lingkungan pengendapan Formasi Tapak. Berdasarkan informasi geologi yang diperoleh, dapat disimpulkan perkembangan fasies lingkungan lagoonal pond, foreshore dalam sub-lingkungan tidal channel sampai pada shoreface-shelf mud facies (mengacu model dari
Reineck and Singh, 1980, Nichols, 2009, Walker \& James, 1992). Dengan kemunculan beberapa fasies tersebut menunjukkan bahwa secara garis besar litologi penyusun Formasi Tapak terendapkan dalam sistem lingkungan pengendapan transisi sampai laut dangkal. Anggota Batugamping Darmakradenan yang tersusun atas batugamping terumbu, kalkarenit dan kalsilutit memiliki pola penyebaran yang linier berarah barat-timur. Penulis menyimpulkan bahwa batugamping tersebut memiliki geometri serta pola pertumbuhan terumbu sebagai barrier reef.

Hasil tersebut juga didukung dari jarak antara singkapan BMS-77 dengan BMS-35 sekitar 1,5 kilometer. Hasil analisis paleontologi menunjukan bahwa kedua satuan batuan ini yaitu Batulempung-gampingan Tapak dengan Batugamping Darmakradenan relatif seumur. 


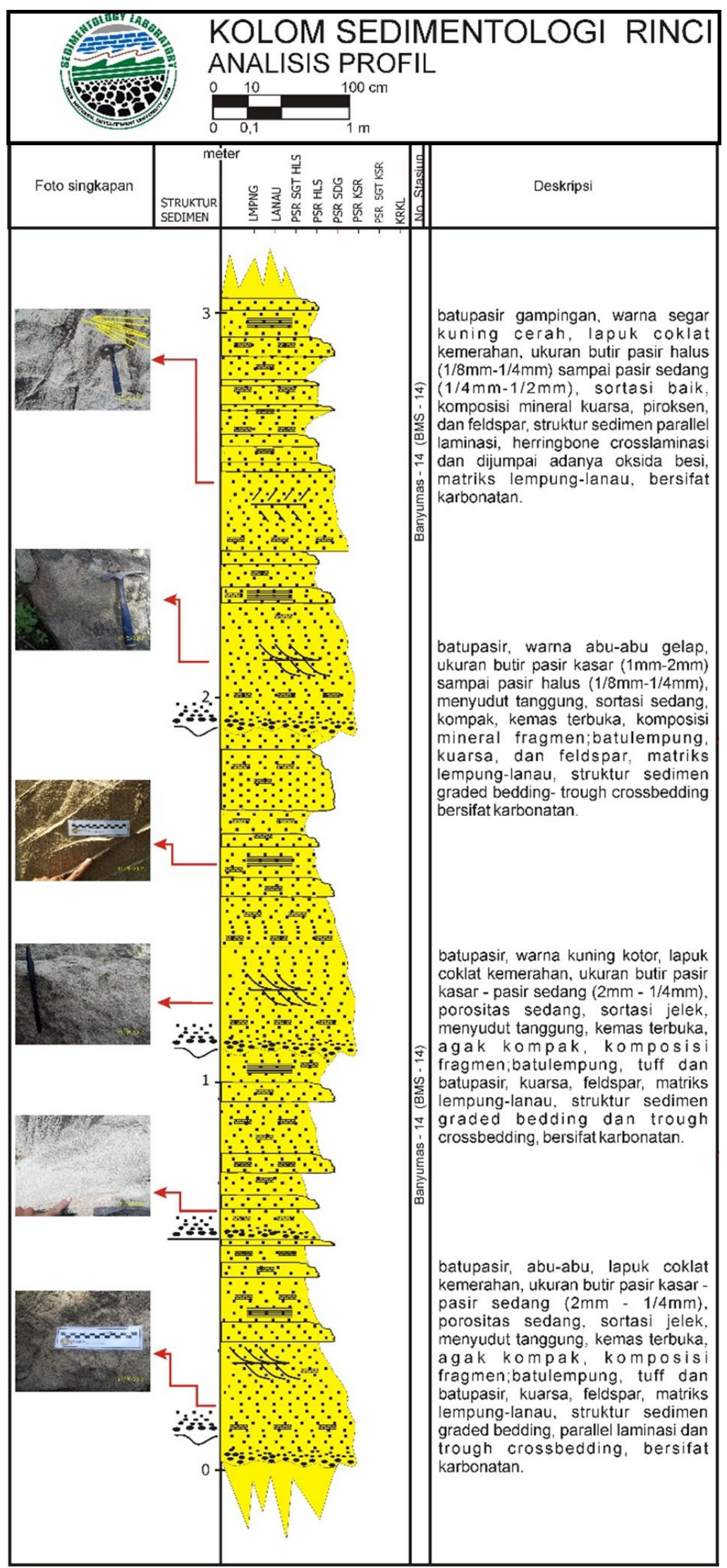

Gambar 5. Analisis profil dan interpretasi model lingkungan pengendapan pada lokasi pengamatan BMS-14 Formasi Tapak. 


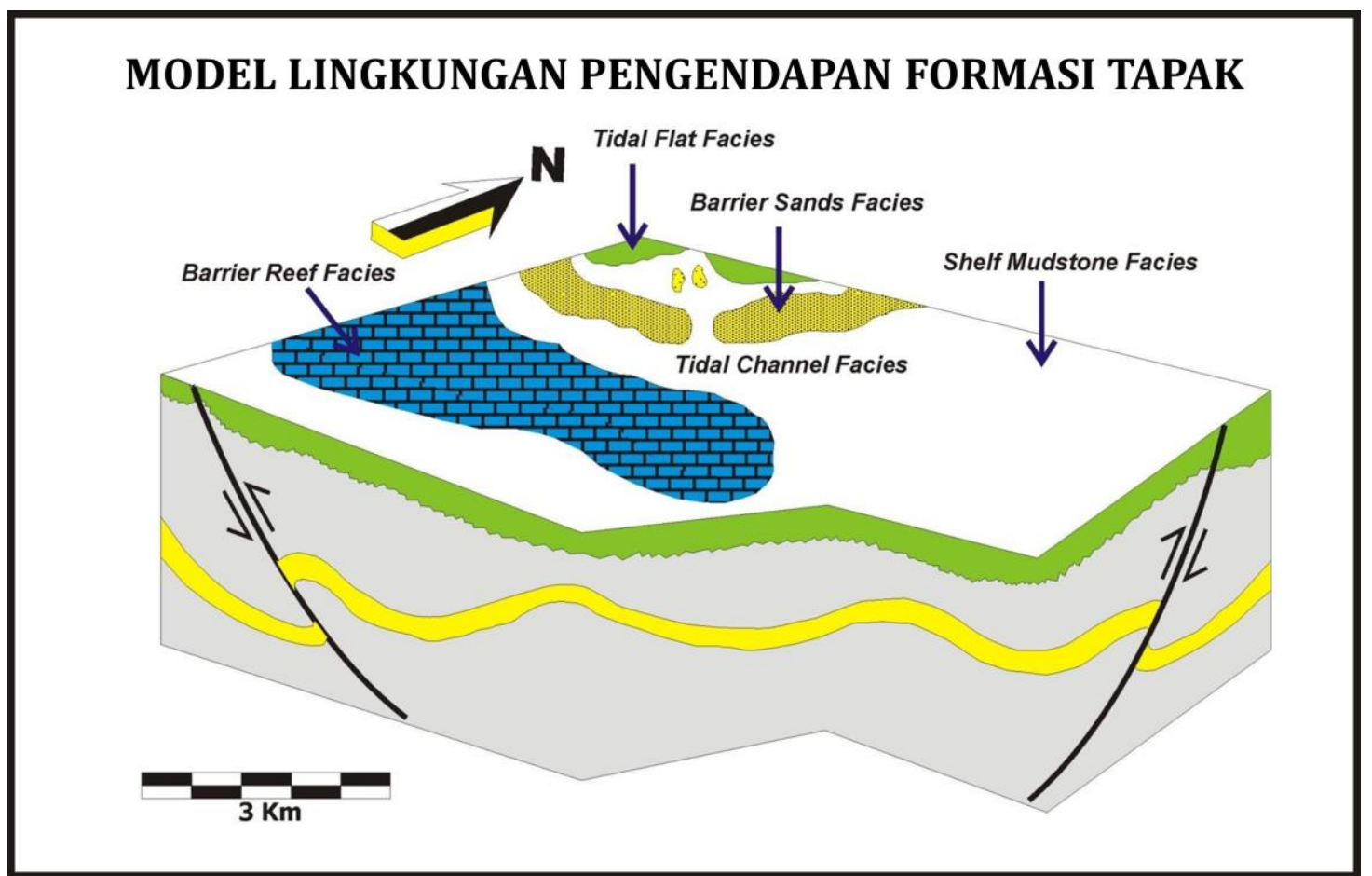

Gambar 8. Model lingkungan pengendapan Formasi Tapak di daerah penelitian pada Kala Pliosen Plistosen pada daerah Penelitian.

Hasil penarikan batas satuan, rekonstruksi stratigrafi juga menandakan bahwa hubungan kedua satuan tesebut adalah menjemari (beda fasies). Kehadiran Fosil Pulleniatina obliquiloculata, Pulleniatina primalis, Sphaeroidinella dehiscens dan Globigerina seminulina mencirikan bahwa kedua satuan tersebut relatif berumur N.20 (Pliosen Awal-Pliosen Akhir) zonasi Bolli \& Saunders, (1985).

Penjelasan mengenai fakta lapangan diatas, maka penulis berkesimpulan bahwa model lingkungan pengendapan Formasi Tapak adalah seperti halnya gambaran lingkungan pengendapan transisi-laut dangkal (mengacu model dari Reineck and singh, 1980, Nichols, 2009, Walker \& James, 1992) yang dibatasi oleh terumbu penghalang yang memiliki pola BaratTimur. Berdasarkan pengukuran arus purba disimpulkan bahwa tinggian purba yang bertindak sebagai daratan utama pada saat pengendapan Formasi Tapak terletak disebelah Barat Laut - Utara (Gambar 8). Kemungkinan tinggian tersebut merupakan hasil deformasi sedimen Pliosen dari Formasi Halang yang telah terlipat dan tersesarkan di Sub-Cekungan Banyumas tersebut.

\section{KESIMPULAN}

Fasies pengendapan yang berkembang pada Formasi Tapak bervariasi, yaitu lagoonal pond, tidal channel in foreshore facies, upper shoreface - shelf mud facies. Pada daerah penelitian ditemukan batugamping terumbu yang terbentuk pada Barrier Reef. Pengukuran arus purba pada struktur sedimen trough crossbedding pada lokasi pengamatan BMS-14, terlihat bahwa arah umum dari transportasi sedimennya berasal dari baratlaut menuju ke tenggara. Berdasarkan pengukuran arus purba kemungkinan terdapat tinggian purba yang bertindak sebagai daratan utama pada saat pengendapan Formasi Tapak terletak disebelah baratlaut-utara.

\section{UCAPAN TERIMA KASIH}

Penulis berterima kasih atas Dr Ir. Suyoto \& Ir. Kuwat Santoso (Alm) sebagai Promotor Akademik. Kepada Dr. Ir. C. Prasetyadi dan Ir. Salatun Said M.T., atas waktu luang yang diberikan untuk berdiskusi. Untuk "PANGEA" 08 terima kasih atas doa serta dukunganya. 


\section{DAFTAR PUSTAKA}

Bolli H.M., dan Saunders J.B., 1985. Oligocene to Holocene low latitude planktic foraminifera. Cambridge University Press.

Djuri, M., Samodra, H., Amin T.C., dan Gafoer, S., 1996. Peta Geologi Lembar Purwokerto, Jawa, skala 1:100.000. Pusat Penelitian dan Pengembangan Geologi, Bandung.

Dunham, R. J., 1962. Classification of Carbonate Rock According to Depositional Texture, in Classification of Carbonate Rocks. A symposium, AAPG men, No.1., p 108121.

Kastowo dan Suwarna, N., 1996. Geologi Lembar Majenang, Jawa, skala 1:100.000. Pusat Penelitian dan Pengembangan Geologi, Bandung.

Muchsin, N., Ryacudu, R., Widyokunto, and Sri Budiyani, Yulihanto, B., Wiyanto, B. Nurjayadi, A., Rahardjo, K., dan Riandra, F. 2002. Miocene Hydrocarbon System of the Southern Central Java Region. Proceeding $31^{s t}$ Annual Convention Indonesian Association of Geologists.

Nichols, G., 2009. Sedimentology and Stratigraphy second edition. WileyBlackwell., A John Wiley \& Sons, Ltd., Publication, The Atrium, Southern Gate, Chichester, West Sussex U.K.

Reineck H. E. And Singh I.B., 1980. Depositional sedimentary environments, Springer- Verlag Berlin Heidelberg, New York America.

Sujanto, F.X. dan Roskamil, 1975. The Geology and Hydrocarbon Aspect of the South Central Java, Proceeding Indonesian Association of Geologist, 4th Annual Meeting, Bandung.

van Bemmelen, R.W., 1949. The Geology of Indonesia, Vol. IA: General Geology of Indonesia and Adjacent Archipelagoes, The Hague.

Wilson, J. L., 1975. Carbonate Facies in Geologic History. New York, SpringerVerlag. 